\title{
PARTISIPASI ORANG TUA DALAM MENGEMBANGKAN KECERDASAN INTRAPERSONAL ANAK USIA DINI
}

\section{Parent Participation in Developing Intrapersonal Intellegence in Early Children}

\author{
Alin Ulpiyati Elan $^{2}$ Sima Mulyadi ${ }^{3}$ \\ Universitas Pendidikan Indonesia Kampus Tasikmalaya ${ }^{123}$ \\ Email: alinulpiyati02@gmail.com ${ }^{1}$ \\ Email: elanmpd@upi.edu ${ }^{2}$ \\ Email: sima_mulyadi@yahoo.com ${ }^{3}$
}

DOI: $10.53754 /$ edusia.v1i1.38

Received: 2021-07-21
Abstract: parental participation is very basic in the development of a child's character, one of
which is intelligence. Intrapersonal intelligence is very important for children, if someone
has a high level of intelligence, he will be able to control his emotions so that the actions
taken are based on the correct knowledge. Therefore, in developing this intrapersonal
intelligence, a stimulus from parents is needed. The purpose behind this research is to
describe the role of parents in developing intrapersonal intelligence of children aged 5-6
years. The researcher uses a case study approach approach, the type of instrumental case
study approach. The selection of research subjects was carried out by purposive sampling,
which consisted of two families. This information collection method is carried out using
interviews, observation, and documentation. This study uses data analysis techniques
created by Miles and Huberman. The results showed that parents play a role in providing
support, parents play a role in providing guidance, parents play a role in uniting children's
activities, parents play a role in providing understanding for children, parents teach children
in emotions, parents play a role in habituation to children.

Keyword: Early childhood; intrapersonal intelligence: parental participation; children

\begin{abstract}
Abstrak: Partisipasi orang tua sangat mendasar dalam kemajuan karakter anak, salah satunya kecerdasan. Kecerdasan intrapersonal sangat penting bagi anak, jika seseorang memiliki kecerdasan ini dengan tingkat tinggi maka akan mampu mengontrol emosinya sehingga tindakan yang dilakukan didasarkan pada pengetahuan yang benar. Oleh karena itu, dalam mengembangkan kecerdasan intrapersonal ini diperlukan stimulus dari orang tua. Maksud dibalik penelitian ini adalah untuk menggambarkan peran orang tua dalam mengembangkan kecerdasan intrapersonal anak-anak usia 5-6 tahun. Peneliti menggunakan metode kualitatif dengan pendekatan studi kasus, jenis pendekatan studi kasus instrumental. Pemilihan subjek penelitian dilakukan dengan cara purposive sampling yaitu terdiri dari dua keluarga. Metode pengumpulan informasi ini, dilakukan dengan menggunakan wawancara, observasi, dan dokumentasi. Penelitian ini menggunakan teknik analisis data yang diciptakan oleh Miles dan Huberman. Hasil penelitian menunjukkan bahwa orang tua berperan dalam memberikan dukungan, orang tua berperan dalam memberikan bimbingan, orang tua berperan dalam memantau kegiatan anak, orang tua berperan memberikan pemahaman bagi anak, orang tua mengajarkan anak dalam meredam emosi, orang tua berperan melakukan pembiasaan pada anak.
\end{abstract}

Kata Kunci: Pariwisata, wisata edukasi, pengembangan desa, pemberdayaan masyarakat 


\section{PENDAHULUAN}

Desa Sukakarsa merupakan salah satu desa di Kabupaten Tasikmalaya yang sebagian besar penduduknya merupakan pasangan reproduktif dan mempunyai anak usia dini. Menurut data dari ibu kades "jumlah penduduk anak usia dini di daerah ini mencapai 925 orang". Tidak hanya itu, warga di desa ini terdiri dari berbagai tingkat ekonomi dan pendidikan yang berbeda, namun tidak pernah ada ketimpangan sosial di antara penduduk. Dapat dijelaskan daerah ini merupakan masyarakat yang beragam. Tidak hanya itu, orang tua di daerah ini juga telah memahami bahwa kewajiban mengurus tumbuh kembang anak ada ditangan orang tua. Kebanyakan ayah di daerah ini bekerja, sementara ibu mengatur anaknya di rumah. Anak usia dini di daerah ini juga sangat beragam, berdasarkan studi pendahuluan dengan berbagai jenis latar belakang, tentunya keadaan setiap orang berbeda-beda. Perbedaan ini sangat mempengaruhi peran orang tua terhadap anakanaknya. Kurangnya pengetahuan tentang pendidikan, akan menghambat pada perkembangan anak. Di daerah ini tidak semua orang tua mengutamakan pendidikan untuk anak-anak di rumah atau keluarga. Adanya pandangan orang tua, mengenai pendidikan anak adalah tanggung jawab lembaga pendidikan. Hal ini, didapatkan pada saat peneliti melakukan observasi di lapangan pada tanggal 4 Juni 2021, pandangan tersebut yaitu ketika anak tidak ingin belajar, orang tua tidak mendampinginya tetapi malah memasukannya les privat, perihal ini karena orang tua belum dapat menciptakan belajar yang menyenangkan dan pada saat anak memiliki bakat yang baik, orang tua tidak mendukung. Dengan permasalahan tersebut anak tidak akan percaya diri serta mandiri. Dalam pelaksanaan penelitian, peneliti menggunakan metode kualitatif yang menekankan pada lingkungan yang sebenarnya, maka data yang ditemukan berasal langsung dari tangan peneliti. Hal ini diungkapkan oleh Anggito \& Setiawan bahwa metode ini memiliki cara yang bersifat fleksibilitas, pengalaman langsung, mendalam, proses menangkap makna, dan pastisifasi aktif secara keseluruhan, dan interpretasi subjek. Oleh karena itu, penelitian yang dilakukan ini berupa deskriptif, dan untuk memperoleh data, peneliti menggunakan teknik Miles\& Huberman. ${ }^{1}$ Penelitian ini menggunakan pendekatan studi kasus pada dua keluarga yang memiliki anak usia 5-6 tahun dan memiliki ciri-ciri kecerdasan intrapersonal. Adapun jenis pendekatan yang akan dilakukan yaitu studi kasus instrumental.

Keluarga merupakan pendidikan pertama yang ditujukkan kepada anaknya yang menanamkan pengetahuan, pengalaman, dan teladan dalam mengembangkan kecerdasan. Allah menitipkan anak kepada orang tuanya. Oleh karena itu, orang tua perlu melindungi, memelihara, memberikan bimbingan, dan pengarahan menuju

1 Anggito, A., \& Setiawan, J. (2018). Metodologi Penelitian Kualitatif. Sukabumi: CV Jejak, hlm. 8. 
masa depannya supaya menjadi orang yang bermanfaat bagi keluarga, masyarakat, agama, bangsa, dan negara. Pernyataan ini didukung Joan Beck yang dikutip oleh Wijayanto dalam jurnalnya yang mengungkapkan bahwa banyak penelitian yang menunjukkan apabila suasana rumah yang hangat dan demokratis bagi anak, kecerdasan anak akan lebih berkembang, daripada suasana yang dingin dan otoritas. ${ }^{2}$ Dapat disimpulkan bahwa peran orang tua juga sangat mempengaruhi dan berperan penting dalam pengembangan karakter anak, terutama dalam kecerdasan intrapersonal.

Menurut Gardner yang dikutip oleh Sujiono mengemukakan bahwa setiap anak memiliki semua kecerdasan, namun hanya tingkat perkembangan yang berbeda. ${ }^{3}$ Salah satu kecerdasan yang penting untuk distimulasi demi kemajuan generasi muda dalam kehidupan selanjutnya adalah kecerdasan intrapersonal. Hendarti mengungkapkan bahwa kecerdasan intrapersonal hanyalah kapasitas untuk memahami diri sendiri, yang dapat menumbuhkan kemajuan konsep diri, harga diri, pengetahuan diri sendiri, kepercayaan diri, keberanian, dan disiplin. ${ }^{4}$ Kemudian Suyadi juga mengatakan kecerdasan ini bukanlah pribadi yang mementingkan diri sendiri, tetapi dapat menumbuhkan anak untuk hidup mandiri serta tidak bergantung pada orang lain. ${ }^{5}$ Berdasarkan hal tersebut, kecerdasan intrapersonal merupakan hal yang penting bagi anak, jika seseorang memiliki kecerdasan ini dengan tingkat tinggi, maka akan mampu mengontrol emosinya sehingga tindakan yang dilakukan didasarkan pada pengetahuan yang benar. Selain itu mempunyai motivasi pada dirinya sendiri untuk mencapai apa yang diharapkannya secara mandiri. Oleh karena itu, dalam mengembangkan kecerdasan intrapersonal ini diperlukan stimulus, yaitu orang tua.

Chalil \& Latuconsina mengungkapkan bahwa belajar dan berlatih dengan rajin dapat mencapai kecerdasan. Namun, hanya ketika anak menyadari bahwa ada faktor lain selain diri mereka sendiri yang membuat mereka pintar barulah dapat memperoleh kecerdasan sejati. Faktor utama adalah Allah SWT, dia-lah yang telah menggerakkan syaraf otak kita, dan membantu orang-orang dengan indera yang dapat digunakan untuk eksplorasi ilmu pengetahuan di bumi ini. Faktor ini adalah jalan menuju kecerdasan manusia yang sejati. Faktor berikutnya adalah kesadaran bahwa orang tua memegang peranan penting dalam upaya dan proses pencapaian

\footnotetext{
2 Wijayanto, A. (2020). Peran Orangtua dalam Mengembangkan Kecerdasan Emosional Anak Usia Dini. Diklus: Jurnal Pendidikan Luar Sekolah, 4(1), 55-65. https://doi.org/10.21831/diklus.v4i1.30263, hlm. 56.

3 Sujiono, Y. N. (2015). Konsep Dasar Pendidikan Anak Usia Dini (ke-8). Jakarta: PT Indeks, hlm. 176.

${ }^{4}$ Hendarti, P. (2013). Peran Orang Tua dalam Optimalisasi Tumbuh Kembang Anak untuk Membangun Karakter Jujur. Prosiding Seminar Nasional Parenting 2013, 34-47. https://doi.org/10.31227/osf.io/zdt3g, hlm.41.

${ }^{5}$ Suyadi. (2015). Teori Pembelajaran Anak Usia Dini dalam Kajian Neurosains (ke-3). Bandung: PT Remaja Rosdakarya, hlm.135.
} 
kecerdasan. ${ }^{6}$ Maka dari itu, orang tua perlu melatih dan mengembangkan kemampuan anak, agar kesadaran anak semakin tinggi meskipun tanpa sarana dan prasarana, yang paling penting orang tua dapat menuntun anak dengan benar.

Tema peran orang tua sangat menarik untuk diteliti. Hal ini bisa dilihat pada karya-karya yang terpublikasi. Salah satu karya yang membahas tema ini adalah karya Monica \& Siti (2020) yang berjudul "Peran Pembelajaran Homeschooling dalam Membentuk Kecerdasan Intrapersonal (Studi di Fikar School Rempoa, Tangerang Selatan)" mengungkapkan dengan proses pembelajaran seperti culture habit ini dapat memberikan pengaruh yang baik kepada kecerdasan intrapersonal anak, sehingga dapat membentuk karakter yang baik dan menjadikan budaya anak untuk mandiri di manapun lingkungan dia berada. ${ }^{7}$ Kemudian karya yang berjudul "Pengaruh Pola Asuh Orang Tua terhadap Kecerdasan Intrapersonal dan Kecerdasan Interpersonal Anak Usia Dini" oleh Rahimah \& Muzdhalifah (2019) dengan hasil penelitian bahwa pola asuh orang tua terhadap kecerdasan intrapersonal dan kecerdasan interpersonal berpengaruh. Adanya hubungan yang baik orang tua dan anak sehingga anak termotivasi. ${ }^{8}$ Penelitian yang berjudul “Upaya Guru dalam Mengembangkan Kecerdasan Intrapersonal Anak Usia Dini melalui Sentra Main Peran di TA Al-Mannar Ponorogo" oleh Ikasari (2020) dengan hasil penelitian bahwa kecerdasan intrapersonal anak usia dini di TA Al-Manaar AlIslamiyah Ngabar sudah berkembang dengan baik melalui kegiatan sentra main peran dengan indikator seperti kesadaran diri, pengendalian emosi, menaati aturan, rasa tanggung jawab juga sudah berkembang dengan baik. Hambatan yang muncul, masih ada anak yang malu dalam memainkan peran, butuh waktu lama untuk main peran dan kurangnya fasilitas penunjang dalam sentra main peran. ${ }^{9}$ Selanjutnya penelitian oleh Cut (2021) yang berjudul "Hubungan antara kecerdasan intrapersonal dengan kecerdasan emosional" dengan hasil penelitian bahwa kecerdasan ini tidak dapat dipisahkan, dikarenakan di dalam kecerdasan emosional mencakup dua kecakapan yaitu kecakapan intrapersonal dan kecakapan interpersonal. Keuda kecerdasan ini merujuk kepada kemampuan-kemampuan memahami diri sendiri, mengelola emosi, memanfaatkan emosi secara produktif, empati, dan membina hubungan. ${ }^{10}$ Kemudian penelitian yang diteliti oleh Afdhilla

${ }^{6}$ Chalil, A., \& Latuconsina, H. (2008). Pembelajaran Berbasis Fitrah. Jakarta: PT Balai Pustaka (Persero).

${ }^{7}$ Monica, N. A., \& Siti, S. (2020). Peran Pembelajaran Homeschooling dalam Membentuk Kecerdasan Intrapersonal (Studi di Fikar School Rempoa, Tangerang Selatan). Jurnal Qiro'ah, 10(2), 1-14.

${ }^{8}$ Rahimah, \& Muzdhalifah. (2019). Pengaruh Pola Asuh Orang Tua Terhadap Kecerdasan Intrapersonal dan Kecerdasan Interpersonal Anak Usia Dini. Al-Athfaal: Jurnal Ilmiah Pendidikan Anak Usia Dini, 2(2), 1-13. https:// doi.org/10.24042/ajipaud.v2i2.4669.

${ }_{9}^{9}$ Ikasari, M. N. (2020). Upaya Guru Mengembangkan Kecerdasan Intrapersonal Anak Usia Dini melalui Sentra Main Peran di TA Al-Mannar Ponorogo. Jurnal Pendidikan Anak Usia Dini, 01(01), 81-99.

10 Cut, M. (2021). Hubungan antara kecerdasan intrapersonal dengan kecerdasan emosional. MUDARRISUNA: Media Kajian Pendidikan Agama Islam, 11(2), 291-305. 
\& Mahendra (2020) yang berjudul "Mengembangkan Multiple Intelligences Dengan Bermain Pada Anak Usia Dini" melalui studi kepustakaan dan didapatkan hasil penelitian bahwa bermain dapat meningkatkan perkembangan kecerdasan majemuk anak, karena bermain dapat mengembangkan aspek kognitif, berpikir abstrak, berpikir kreatif, sosial-emosional, motorik, bahasa atau komunikasi, dan dapat pula mengembangkan kreativitas. Maka dapat disimpulkan bahwa penelitian tentang kecerdasan intrapersonal anak masih belum banyak diterapkan pada masyarakat luas dan belum semua orang memahami peran orang tua dalam mengembangkan kecerdasan intrapersonal anak. ${ }^{11}$

Berdasarkan pendahuluan yang diatas, penulis merasa terdorong untuk melaksanakan penelitian yang berjudul: "Peran Orang tua dalam Mengembangkan Kecerdasan Intrapersonal Anak Usia 5-6 tahun". Melalui penelitian ini diharapkan dapat mengungkapkan makna yang terkandung dari peran orang tua dalam mengembangkan perkembangan intrapersonal anak usia dini, sehingga penelitian ini dapat bermanfaat bagi orang tua yang mempunyai anak usia dini ataupun pihakpihak lain yang terkait.

\section{PEMBAHASAN}

Setiap orang tua mempunyai kewajiban dan tugas yang sangat mendasar. Junihot mengatakan bahwa orang tua perlu menanamkan nilai norma yang berlaku dimulai pada saat anak dilahirkan, diasuh, dibesarkan, serta diarahkan ketika beranjak dewasa. Orang tua juga perlu menumbuhkan potensi yang ada dalam pribadi anak dengan memberikan teladan, serta menumbuhkan perkembangan pribadi yang penuh tanggung jawab dan kasih sayang. Karunia berharga bagi orang tua yaitu ketika anak-anak tumbuh dengan berbagai bakat masing-masing, dan diibaratkan sebagai perhiasan dunia. ${ }^{12}$

Menurut Utami Munandar yang dikutip oleh Susanto dalam bukunya mengungkapkan sikap orang tua dalam mendukung perkembangan potensi anak meliputi: 1) orang tua memperhatikan penilaian anak dan mendorong anak untuk menyatakan pendapat dari sudut pandangnya, 2) orang tua memberikan kesempatan berpikir, merenung, dan berfantasi kepada anak, 3) orang tua tidak menghalangi anak untuk menentukan pilihan mereka sendiri, 4) orang tua mendorong anak untuk mengajukan banyak pertanyaan, 5) orang tua memperhatikan ketika anak perlu mencoba, melakukan, dan apa yang dihasilkan, 6) orang tua mendukung serta mendorong kegiatan anak, 7) orang tua menikmati

11 Afdhilla, A. B., \& Mahendra, S. A. (2020). Mengembangkan Multiple Intelligences Dengan Bermain Pada Anak Usia Dini. Jurnal CARE, 7(1), 27-35. http:/ /e-journal.unipma.ac.id/index.php/JPAUD.

12 Junihot, S. (2012). Setiap Anak Bisa Pintar (ke-1). Bandung: ANDI, hlm. 4. 
kebersamaan dengan anak, 8) orang tua perlu memberikan pengakuan yang benar kepada anak, 9) orang tua mendorong anak untuk bekerja sendiri, 10) partisipasi di antara orang tua dan anak harus diatur, sehingga hubungan membaik. ${ }^{13}$

Orang tua memiliki peran dalam mengembangkan kecerdasan intrapersonal anak usia dini, maka orang tua pada situasi ini harus meningkatkan tugasnya. Setelah peneliti observasi dan wawancara di lapangan, peran orang tua terhadap perkembangan kecerdasan intrapersonal anak usia 5-6 tahun di RW 09 Desa Sukakarsa Kecamatan Sukarame memiliki 6 peran yaitu:

\subsubsection{Peran orang tua dalam memberikan dukungan}

Slameto dalam bukunya mengatakan bahwa orang tua berpartisipasi dalam mendukung keberhasilan anak, salah satunya dalam hal belajar. Dukungan orang tua kepada anaknya tidak hanya diberikan melalui ucapan, dan juga diberikan melalui tindakan, hal ini dapat membantu menstimulasi semangat belajar anak. Ada beberapa peran yang dapat dilakukan orang tua dalam mendukung anak diantaranya: ikut terlibat dalam kegiatan yang dilakukan oleh anak, mmemperhatikan kondisi fisik atau psikis anak, memahami dan mengatasi kesulitan pada anak, serta mendorong anak dengan menyediakan fasilitas yang memadai. ${ }^{14}$

Hmmm, iya saya selalu memuji dia, dengan kata 'wah ade hebat'. Kemudian, kadang saya membelikan hadiah seperti makanan sebagai apresiasi, agar dapat beusaha lebih baik lagi. (kutipan wawancara Ibu NNA)

Eumm, apa yah, kadang sih saya suka bilang 'ade pasti bisa'... saya kadang memberikan reward sih, karena saya selalu membelikan yang dibutuhkannya saja seperti jalan-jalan. (kutipan wawancara Ibu HH)

Di wilayah ini cara orang tua dalam mendukung anaknya adalah dengan memberi dorongan atau melalui hadiah. Hadiah tersebut berupa pujian atau benda, dan orang tua akan memberikannya, jika anak berprilaku baik. Seperti yang dilakukan oleh orang tua NNA dan HH mengakui memberikan anak hadiah ketika mampu berusaha sendiri, hadiah tersebut berupa makanan atau jalan-jalan. Pemberian semacam ini dianggap oleh orang tua sangat efektif dalam mendukung anak.

13 Susanto, A. (2014). Perkembangan Anak Usia Dini: Pengantar dalam Berbagai Aspeknya (ke-3). Jakarta: Kencana. Hlm. 125

14 Slameto. (2010). Belajar dan Faktor-faktor yang mempengaruhinya (ke-5). Jakarta: Rineka Cipta, hlm. 54. 


\subsubsection{Peran orang tua dalam memberikan bimbingan pada anak}

Orang tua sebagai teladan bagi anak. Oleh karena itu, orang tua harus berhati-hati dalam berbicara didepan anak, menggunakan bahasa yang baik, karena anak usia dini adalah peniru yang hebat, mereka tidak hanya meniru pada objek-objek yang dilihat tetapi tokoh yang ada dalam film juga dapat ditiru. ${ }^{15}$

Maka dari itu, orang tua yang demokratis, serta mampu mendengarkan dan mengedepankan kepentingan anak merupakan orang tua yang baik. Mereka bertanggung jawab dalam membimbing anak sehingga ia tetap berada di jalan yang benar. Ketika anak tumbuh menjadi baik, maka orang tua akan bangga, hal ini mungkin orang tua mampu memenuhi kebutuhan anak secara maksimal. ${ }^{16}$

...Iya, tentunya saya terlibat dalam kegiatan anak, agar saya dapat membenarkan anak ketika melakukan kesalahan (kutipan wawancara ibu NNA)

...Hmm, pastinya saya ikut terlibat dong, kan kita perlu mengetahui anak melakukan kegiatan apa saja (kutipan wawancara ibu $\mathrm{HH}$ )

Orang tua di wilayah ini ikut terlibat dalam kegiatan anak, maka akan lebih mudah mengetahuinya jika anak tersebut melakukan kesalahan, sehingga mereka dapat membimbing anak lebih baik. Peneliti menemukan orang tua yang membimbing anakanya itu dengan memberikan kesempatan bicara terlebih dahulu, setelah itu baru dinasehati dengan berkata minta maaf, orang tua juga mengakui dia jarang memberikan hukuman, hanya cukup dinasehati dan tidak mengulanginya lagi.

Penjelasan diatas menunjukkan bahwa peran orang tua dalam memberikan bimbingan kepada anak sangat berpengaruh. Membimbing anak merupakan hal yang penting. Selain itu peran orang tua dalam membimbing anak juga akan mempengaruhi kecerdasan intrapersonal.

\subsubsection{Peran orang tua tua dalam memantau kegiatan anak}

Orang tua mempunyai kewajiban dalam memantau kegiatan anak, memantau disini berhubungan dengan gaya pengasuhan yang diberikan orang tua, jika gaya pengasuhan orang tua tepat, maka anak akan memiliki kecerdasan intrapersonal yang baik. Teori Doyle yang dikutip Nenny dalam bukunya mengatakan, yang dibutuhkan oleh anak adalah rasa cinta dan rasa damai, mereka mencarinya dari figur ayah dan ibu. Misalnya, ketika anak berani mengambil sebuah keputusan, maka pribadi mereka tumbuh sehingga dapat menumbuhkan rasa percaya diri yang

${ }^{15}$ Hendarti, P. (2013). Peran Orang Tua dalam Optimalisasi Tumbuh Kembang Anak untuk Membangun Karakter Jujur. Prosiding Seminar Nasional Parenting 2013, 34-47. https://doi.org/10.31227/osf.io/zdt3g, hlm. 43-44.

${ }^{16}$ Nenny, M. (2020). Emosional Anak Usia Dini (ke-1). Jakarta: Kencana, hlm. 43-44. 
tinggi. Rasa aman tersebut merupakan cara orang tua menjaga anak dari hal yang tidak seharusnya diperoleh. ${ }^{17}$

Saya juga selalu memantau, jika kegiatannya itu main hp, takut buka situs yang sesuai usianya.... tapi sih dia suka liat video Barbie (kutipan wawancara ibu NNA)

Kalau saya peduli banget pada prilaku anak, makanya selalu dipantau setiap saat, takutnya melakukan kegitan yang membahayakan anak (kutipan wawancara ibu $H H)$

Pada wilayah ini, peran orang tua dalam memantau kegiatan anak sudah diterapkan, mereka selalu memberikan sikap terbuka pada anak, ketika anak bermain dirumah ataupun di luar rumah mereka selalu memantaunya, karena mereka peduli pada prilaku anak, sehingga dalam memberikan izin mereka tidak membiarkan main terlalu jauh. Hal tersebut memberika rasa aman yang baik untuk anak.

\subsubsection{Peran orang tua dalam memberikan pemahaman pada anak}

Dalam masa perkembangan dan pertumbuhan, anak membutuhkan orang dewasa, sedangkan orang yang pertama dan bertanggung jawab pada mereka adalah orang tua. Prianti mengungkapkan bahwa orang tua juga memberikan pembelajaran dalam hal komunikasi dan interaksi pada orang disekitarnya. Masa anak-anak adalah masa ketika anak mencari cara apa yang mereka butuhkan dari dunia, dan apa yang dibutuhkan dunia untuk mereka. ${ }^{18}$

Saya sih, suka memberikan penjelasan dulu mengenai kebaikan dan kelemahan yang anak inginkan...(kutipan wawancara ibu NNA)

Saya memberikan pemahaman kepada anak bahwa setiap permasalahan itu pasti ada solusinya.... (kutipan wawancara ibu $\mathrm{HH}$ )

Orang tua selalu memberi pemahaman dan memberi kesempatan kepada anak untuk mengungkapkan keinginannya. Hal tersebut diakui orang tua dapat mengembangkan intrapersonal anak, daripada membentak dan mengikat kesempatan anak, contohnya orang tua meminta anak untuk berpikir sebelum bertindak, ketika anak membeli ice cream namun kondisi tubuhnya kurang sehat, orang tua memberikan pemahaman bahwa kalau makan ice cream ketika batuk nanti gak akan sembuh batuknya, dan ketika anak meminta saran kepada ibunya agar temannya tidak berantem, orang tua memberikan pemahaman kepada anak tersebut bahwa bermain bersama-sama akan lebih senang daripada main sendirian.

${ }^{17}$ Ibid., hlm. 64-65.

18 Prianti, D. D. (2011). Studi fenomenologi tentang pengalaman komunikasi antar pribadi orang tua-anak terhadap pemahaman anak pada norma-norma perilaku (Kasus pada anak penyandang autisme). Jurnal Ilmiah Komunikasi Makna, 2(1), 1-8. http://jurnal.unissula.ac.id/index.php/makna/article/view/97, hlm. 2. 


\subsubsection{Peran orang tua mengajarkan anak dalam meredam emosi}

Kecerdasan intrapersonal anak erat kaitannya dengan pengendalian emosi. Menurut Copple dan Bredekamp yang dikutip oleh Utami mengungkapkan bahwa pada dasarnya anak masih egosentris, tetapi mereka mulai mengenali perbedaan dan kesamaan dirinya dengan orang lain dari sudut pandangnya sendiri, anak bersikap senang dan empati menikmati kebersamaan dengan orang lain, mereka belajar bertanggung jawab, berkompeten dalam bidangnya, serta dapat dipercaya dalam melaksanakan tugas dengan tepat dan cermat. Anak-anak juga mulai berprilaku baik, sehingga mereka dapat mengarahkan dan mengendalikan diri dengan mengetahui apakah mereka dapat melakukannya atau tidak, dan mereka memiliki perasaan yang kuat dalam meningkatkan imajinasinya. Kapasitas ini menunjukkan bahwa anak-anak memiliki kecerdasan intrapersonal. Penampilan pada anak dapat menunjukkan perubahan perasaan, seperti tersenyum, marah, sedih, masam. Penampilan ini akan mempengaruhi pengakuan sosial dan mempengaruhi lingkungan mental pada anak. Ketika orang tua menunjukkan perilaku yang tidak baik, dia akan mendapatkan respons yang kurang baik pula, sehingga anak akan beranggapan tidak disayangi atau diabaikan. Sebaliknya, ketika orang tua memberikan perilaku yang positif, anak tersebut akan mendapatkan respon yang bagus. 19

Ketika anak saya marah, berarti ada yang tidak disukai oleh dia, atau ada yang mengambil kesukaannya. Saya sih, selalu memberikan pelukan dulu, agar anak tenang.... (kutipan wawancaran ibu NNA)

Saya sih, selalu mengajarkan pada anak bahwa marah itu tidak baik. Untuk meredamkan emosi marahnya, mungkin dengan cara di ajak keluar jalan-jalan. (kutipan wawancara ibu $\mathrm{HH}$ )

Orang tua di wilayah ini meminta anak-anak untuk berfikir sebelum bertindak, dan tidak mengutamakan emosi, sebelum mencari akar penyebab atau insiden tersebut. Contohnya, ketika anak berselisih dengan teman mainnya, orang tua perlu melatih anak untuk menggambarkan apa yang terjadi, ketika anak nada bicaranya tinggi, maka anak itu sedang marah, mungkin ada hal yang tidak dia sukai. Oleh karena itu, cara orang tua yang biasa lakukan yaitu langsung memberikan pelukan atau di mengajaknya pergi keluar jalan-jalan.

\subsubsection{Peran orang tua dalam melakukan pembiasaan}

Pada saat anak dilahirkan, mereka membutuhkan orang lain dalam memenuhi kebutuhannya, orang tersebut adalah orang tua. Sesuai bertambahnya usia, orang

19 Utami, A. D. (2012). Peningkatan Kecerdasan Intrapersonal dan Kecerdasan Interpersonal melalui Pembelajaran Project Approach Improving Intrapersonal Intelligence and Interpersonal. 7(2), 138-152, hlm. 144. 
tua perlu melatih kemampuan anak dalam menolong keperluan sehari-hari seperti makan, minum, buang air besar, buang air kecil, dan berpakaian. ${ }^{20}$ Pada wilayah ini mengakui bahwa orang tua selalu terlibat dalam membiasakan dan melakukan halhal sederhana, dengan begitu anak akan terbiasa melakukannya, pembiasaan yang dilakukan orang tua terhadap kegiatan anak yaitu yang sesuai dengan kemampuan anak. Misalnya orang tua membiasakan anak ikut membantu melipat baju, orang tua membiasakan anak memilih pakaian sesuai yang dia inginkan, orang tua membiasakan anak ikut membantu menyapu dan membereskan tanaman-tanaman, dan membiasakan mengambil handuk sebelum mandi. Pernyataan ini sesuai dengan teori bandura yang dikutip oleh Ainiyah mengatakan bahwa cara memperhatikan dan meniru prilaku pada orang dewasa adalah demonstrasi belajar. Contohnya apabila anak dibesarkan di tempat taruhan, dia biasanya akan bermain taruhan, sebaliknya bahwa taruhan itu tidak dapat diterima. ${ }^{21}$ Oleh karena itu, peran orang tua dalam melakukan pembiasaan ini sangat berpengaruh.

\section{KESIMPULAN}

Berdasarkan hasil penelitian yang dilaksanakan peneliti terkait peran orang tua dalam mengembangkan kecerdasan intrapersonal anak usia 5-6 tahun di RW 09 Desa Sukakarsa Kecamatan Sukarame sudah diterapkan, peran tersebut terdiri dari orang tua dalam mendukung anaknya, dengan cara memberi dorongan atau melalui hadiah. Hadiah tersebut berupa pujian atau benda, dan orang tua akan memberikannya, jika anak berprilaku baik. Kemudian dalam memberikan bimbingan kepada anak, dengan cara memberikan kesempatan bicara terlebih dahulu, setelah itu baru dinasehati dengan berkata minta maaf, orang tua juga mengakui dia jarang memberikan hukuman, hanya cukup dinasehati dan tidak mengulanginya lagi. Selanjutnya dalam memantau kegiatan anak, dengan cara orang tua selalu memberikan sikap terbuka pada anak, ketika anak bermain dirumah ataupun di luar rumah mereka selalu memantaunya. Orang tua juga memberikan pemahaman pada anak, dengan cara memberi kesempatan anak untuk mengatakan keinginannya. Hal tersebut diakui orang tua dapat mengembangkan intrapersonal anak, daripada membentak dan mengikat kesempatan anak. Tidak hanya itu, Orang tua juga mengajarkan anak dalam meredam emosi, dengan cara meminta anak-anak untuk berfikir sebelum bertindak, dan tidak mengutamakan

${ }^{20}$ Nenny, M. (2020). Emosional Anak Usia Dini (ke-1). Jakarta: Kencana, hlm.16.

${ }^{21}$ Ainiyah, Q. (2017). Social Learning Theory dan Perilaku Agresif Anak dalam Keluarga. Jurnal Ilmu Syari'ah Dan Hukum, 2(1), 94-98. http://ejournal.iainsurakarta.ac.id/index.php/al-ahkam/article/download/789/242, hlm. 96. 
emosi, sebelum mencari akar penyebab atau insiden tersebut. Dan yang terakhir tentunya orang tua melakukan pembiasaan, dengan dimulai dari hal-hal sederhana, dengan begitu anak akan terbiasa melakukannya, pembiasaan yang dilaksanakan orang tua dalam kegiatan anak disesuaikan dengan kemampuannya.

Berdasarkan kesimpulan penelitian diatas, peneliti memperoleh implikasi dari hasil penelitian, pertama, selama penelitian, kegiatan yang dilakukan tidak ada setingan, maka dari itu penelitian ini berproses secara apa adanya. Sehingga dengan adanya penelitian ini, wawasan orang tua dapat bertambah. Kedua, kecerdasan intrapersonal ini dapat membantu anak dalam menyadari dirinya sendiri, sehingga kepribadian anak akan berkembang, dan mampu mengelola dirinya di masa yang akan datang.

\section{REFERENSI}

Afdhilla, Alfien Baddrin, and Syarizal Agam Mahendra. 2020. “Mengembangkan Multiple Intelligences Dengan Bermain Pada Anak Usia Dini." Jurnal CARE 7 (1): 27-35.

Ainiyah, Qurrotul. 2017. “Social Learning Theory Dan Perilaku Agresif Anak Dalam Keluarga." Jurnal Ilmu Syari'ah Dan Hukum 2 (1): 94-98.

Anggito, Albi, and Johan Setiawan. 2018. Metodologi Penelitian Kualitatif. Sukabumi: CV Jejak.

Chalil, Achjar, and Hudaya Latuconsina. 2008. Pembelajaran Berbasis Fitrah. Jakarta: PT Balai Pustaka (Persero).

Cut, Maitrianti. 2021. "Hubungan Antara Kecerdasan Intrapersonal Dengan Kecerdasan Emosional." MUDARRISUNA: Media Kajian Pendidikan Agama Islam 11 (2): 291-305.

Hendarti, Permono. 2013. "Peran Orang Tua Dalam Optimalisasi Tumbuh Kembang Anak Untuk Membangun Karakter Jujur." In Prosiding Seminar Nasional Parenting 2013, 34-47. Surakarta: Universitas Muhammadiyah Surakarta. https://doi.org/10.31227/osf.io/zdt3g.

Ikasari, Murni Nur. 2020. “Upaya Guru Mengembangkan Kecerdasan Intrapersonal

Anak Usia Dini Melalui Sentra Main Peran Di TA Al-Mannar Ponorogo." Jurnal

Pendidikan Anak Usia Dini 01 (01): 81-99.

Junihot, Simanjuntak. 2012. Setiap Anak Bisa Pintar. Ke-1. Bandung: ANDI.

Monica, Nur Azizah, and Shopiyah Siti. 2020. "Peran Pembelajaran Homeschooling

Dalam Membentuk Kecerdasan Intrapersonal (Studi Di Fikar School Rempoa,

Tangerang Selatan)." Jurnal Qiro'ah 10 (2): 1-14.

Nenny, Mahyuddin. 2020. Emosional Anak Usia Dini. Ke-1. Jakarta: Kencana.

Prianti, Desi Dwi. 2011. “Studi Fenomenologi Tentang Pengalaman Komunikasi Antar Pribadi Orang Tua-Anak Terhadap Pemahaman Anak Pada NormaNorma Perilaku (Kasus Pada Anak Penyandang Autisme)." Jurnal Ilmiah Komunikasi Makna 2 (1): 1-8.

Rahimah, and Muzdhalifah. 2019. “Pengaruh Pola Asuh Orang Tua Terhadap 
Kecerdasan Intrapersonal Dan Kecerdasan Interpersonal Anak Usia Dini." AlAthfaal: Jurnal Ilmiah Pendidikan Anak Usia Dini 2 (2): 1-13. https:/ / doi.org/10.24042/ajipaud.v2i2.4669.

Slameto. 2010. Belajar Dan Faktor-Faktor Yang Mempengaruhinya. Ke-5. Jakarta: Rineka Cipta.

Sujiono, Yuliani Nurani. 2015. Konsep Dasar Pendidikan Anak Usia Dini. Ke-8. Jakarta: PT Indeks.

Susanto, Ahmad. 2014. Perkembangan Anak Usia Dini: Pengantar Dalam Berbagai Aspeknya. Ke-3. Jakarta: Kencana.

Suyadi. 2015. Teori Pembelajaran Anak Usia Dini Dalam Kajian Neurosains. Ke-3. Bandung: PT Remaja Rosdakarya.

Utami, Ade Dwi. 2012. "Peningkatan Kecerdasan Intrapersonal Dan Kecerdasan Interpersonal Melalui Pembelajaran Project Approach Improving Intrapersonal Intelligence and Interpersonal" 7 (2): 138-52.

Wijayanto, Arif. 2020. "Peran Orangtua Dalam Mengembangkan Kecerdasan Emosional Anak Usia Dini." Diklus: Jurnal Pendidikan Luar Sekolah 4 (1): 55-65. https:/ / doi.org/10.21831/diklus.v4i1.30263. 